Columbia Law School

Scholarship Archive

2008

\title{
Sovereign Wealth Funds and Corporate Governance: A Minimalist Response to the New Mercantilism
}

Ronald J. Gilson

Columbia Law School, rgilson@law.columbia.edu

Curtis J. Milhaupt

milhaupt@law.stanford.edu

Follow this and additional works at: https://scholarship.law.columbia.edu/faculty_scholarship

Part of the Law and Economics Commons

\section{Recommended Citation}

Ronald J. Gilson \& Curtis J. Milhaupt, Sovereign Wealth Funds and Corporate Governance: A Minimalist Response to the New Mercantilism, 60 StAN. L. Rev. 1345 (2008).

Available at: https://scholarship.law.columbia.edu/faculty_scholarship/896

This Article is brought to you for free and open access by the Faculty Publications at Scholarship Archive. It has been accepted for inclusion in Faculty Scholarship by an authorized administrator of Scholarship Archive. For more information, please contact scholarshiparchive@law.columbia.edu. 


\section{SOVEREIGN WEALTH FUNDS AND CORPORATE GOVERNANCE: A MINIMALIST RESPONSE TO THE NEW MERCANTILISM}

\section{Ronald J. Gilson* \& Curtis J. Milhaupt**}

INTRODUCTION.

I. THE SOVEREIGN WEALTH FUND PHENOMENON

II. TWO FACES OF SWF EQUITY INVESTMENTS

III. A MINIMALIST SOLUTION: VOTE SUSPENSION …….....................................1362

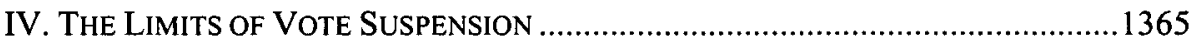

A. The Problem of Underinclusion ............................................................1365

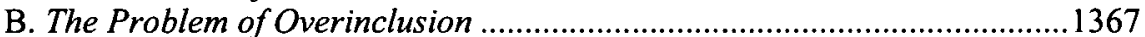

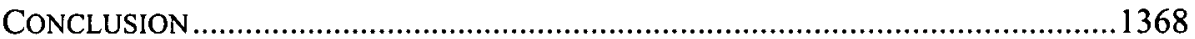

\section{INTRODUCTION}

Keynes taught years ago that international cash flows are always political. ${ }^{1}$ Western response to the enormous increase in the number and the assets of sovereign wealth funds (SWFs), and other government-directed investment vehicles that often get lumped together under the SWF label, proves Keynes right. To their most severe critics, SWFs are a threat to the sovereignty of the nations in whose corporations they invest. The heat of the metaphors matches

* Meyers Professor of Law, Stanford Law School, Stern Professor of Law and Business, Columbia Law School, and Fellow, European Corporate Governance Institute.

** Fuyo Professor of Japanese Law, Albert E. Cinelli Enterprise Professor of Law, and Director of the Center for Japanese Legal Studies, Columbia Law School. The authors appreciate helpful comments by Luca Enriques, Jeff Gordon, and Nicholas Howson on an earlier draft of this Article. Responses of participants at a workshop of the Center on Financial Law at Seoul National University, a conference sponsored by the Program on Alternative Investments at the Columbia Business School, and a conference on Shareholder Rights, Shareholder Voting, and Corporate Performance in Calgiri, Italy were useful in shaping the proposal presented in this Article. Jenna Levine and Peter Conti-Brown provided very helpful research assistance.

1. See John Maynard Keynes, National Self-Sufficiency, 22 YALE REV. 755 (1933). 
the volume of the complaints. The nations whose corporations are targets of investments are said to be threatened with becoming "sharecropper" states if ownership of industry moves to foreign-government absentee holders. ${ }^{2}$ More tempered critics fear that SWFs will make decisions for political, not economic reasons. ${ }^{3}$ Calls for both domestic and international regulation of sovereign wealth funds' investments are now a daily occurrence. ${ }^{4}$ In this Article we frame a minimalist response to concerns over SWFs.

The high profile controversy over the rise of SWFs is one- but only oneof the frictions that result from the interaction of two very different conceptions of the role of government in a capitalist economy-"state capitalism as opposed to market capitalism." In the form of market capitalism that has developed in the advanced economies, to be sure with fits and starts, the individual company is the unit whose value is maximized. Prohibitions against government subsidies and preferences reflected in WTO and European Union rules are designed to prevent governments from shifting the level of profit maximization from the company to the state. In contrast, some major developing countries (China foremost among them) increasingly reflect a form of state capitalism-what we call the new mercantilism. In this form, the country is the unit whose value is to be maximized, with a corresponding increase in the role of the national government as a direct participant in and coordinator of the effort. For the developed economies, the belief that free trade and competition amongst companies increases GDP at the national level is an article of faith: the market polices the tautology. For developing economies, particularly those whose enterprises must compete with companies from more advanced economies, the state, acting through SWFs, through direct ownership of operating companies, and through regulation, seeks to level the playing field. For the new mercantile capitalism, the government attempts to ensure that company-level behavior results in country-level maximization of economic, social, and political benefits.

Although SWFs constitute only one mechanism of state involvement in the economy, they have attracted great attention because for some commentators they are the current face of this tension between competing forms of capitalism.

2. David R. Francis, Will Sovereign Wealth Funds Rule the World?, CHRISTIAN SCI. MONITOR, Nov. 26, 2007, at 16 (quoting Warren Buffett).

3. For example, Sen. Chuck Schumer recently stated with respect to SWFs, "So the bottom line is that we don't know if their decisions are made exclusively on an economic basis." James Politi, Sovereign Funds Face US Threat, FIN. TIMES, Feb. 14, 2008, at 8.

4. See, e.g., Bob Davis, U.S. Pushes Sovereign Funds to Open to Outside Scrutiny, Wall St. J., Feb. 26, 2008, at A1; Robert M. Kimmitt, Public Footprints in Private Markets: Sovereign Wealth Funds and the World Economy, FoREIGN AFF., Jan./Feb. 2008, at 119; Peter Thal Larsen, SWFs Warned to Adopt Code, Fin. TimES, Jan. 23, 2008, at 19; James Surowiecki, Sovereign Wealth World, NEW YORKER, Nov. 26, 2007, at 70.

5. See, e.g., Peter S. Goodman \& Louise Story, Overseas Investors Buying U.S. Holdings at Record Pace, N.Y. TIMES, Jan. 20, 2008, at Al (quoting Prof. Jeffrey E. Garten, Yale School of Management). 
Lawrence Summers has pointed out that the cross-border activities of SWFs and other sovereign investment vehicles have reversed the trend toward privatization that swept over the globe in the past quarter century. ${ }^{6}$ Governments are now accumulating stakes in what were purely private entities. As one commentator argues,

these trends [in the growth of SWFs and their investment activities] involve a dramatic increase in the role of governments in the ownership and management of national assets. This characteristic is unnerving and disquieting. It calls into question our most basic assumptions about the structure and functioning of our economies and the international financial system.

Looking behind the rhetoric, SWFs' investments have attracted attention as a result of two factors, one economic, the other tied to national regulation. On the economic side are the large accumulations of government wealth SWFs represent, together with changes in how this wealth is invested. The great success of Asian exporting nations, especially China, and the rapid rise in oil prices have dramatically increased the foreign currency reserves of nations with trade- and commodity-based economies. China's foreign currency reserve of $\$ 1.4$ trillion is mentioned almost daily in the U.S. media. ${ }^{8}$ Private analysts estimate that with oil prices at the now-modest level of $\$ 70$ per barrel, $\$ 2$ billion of new petrodollars enter world financial markets every day. ${ }^{9}$

Also, reserve-rich countries have begun to change their investment strategy. Until recently, these surpluses were conservatively invested, heavily in U.S. treasury securities and other national government bonds. Capital was recycled without economic or political disruption. ${ }^{10}$ That pattern has changed, but for economic reasons rather than because of changes in international relations or foreign policy. Many governments have recently announced plans to shift investment strategies for sovereign assets from conservative holdings of

6. Lawrence Summers, Op-Ed, Sovereign Funds Shake the Logic of Capitalism, FIN. TIMES, July 30, 2007, at 11 .

7. Sovereign Wealth Fund Acquisitions and Other Foreign Government Investments in the United States: Assessing the Economic and National Security Implications: Hearing Before the S. Comm. on Banking, Housing and Urban Affairs, 110th Cong. (2007) [hereinafter Sovereign Wealth Fund Hearing] (testimony of Edwin M. Truman, Senior Fellow, Peterson Institute for International Economics).

8. See, e.g., James Fallows, The \$1.4 Trillion Question, ATlantic MONTHLY, Jan./Feb. 2008 , at 36 .

9. MCKInSEy \& Co., The New Power Brokers: How OIL, Asia, HedGe Funds, AND Private Equity are Shaping Global Capital Markets 45 (2007), available at http://www.mckinsey.com/mgi/publications/The_New_Power_Brokers/.

10. From time to time commentators noted that the U.S. had become reliant on these investments to finance its trade deficit, and U.S. policymakers sometimes expressed concern over the high level of U.S. government debt owed to the Chinese government. See CRAIG K. Elwell et al., Congressional Research Service, Is China a Threat to the U.S. ECONOMY? 43-44 \& n.80 (2007), However, the stability of the pattem allayed all but occasional concern. 
government bonds to higher-risk/higher-return investments in equities or corporate acquisitions. ${ }^{11}$ Even the Norwegian Government Pension Fund, the most conservative of the sovereign wealth funds, has increased its allocation to equity by half-from $40 \%$ to $60 \%$ of its portfolio. ${ }^{12}$ China has also signaled its intent to increase its equity investments, both in its sovereign wealth funds and in the portfolio of the government pension fund. ${ }^{13}$ The announced reason for these changes in portfolio strategy is straightforward. Like the Bush administration's plan to shift social security investments into the capital markets, reserve-rich countries say they are seeking the higher returns and greater diversification associated with investing in a broader range of asset classes.

The result has been a boom in high-profile, and highly controversial investments. The Abu Dhabi Investment Authority (ADIA) recently acquired Citibank debt convertible into $4.9 \%$ of its common stock, which would make ADIA one of the bank's largest shareholders. ${ }^{14}$ A Chinese fund purchased just under $10 \%$ of Blackstone's equity in $2007 .{ }^{15}$ Chinese and Singaporean entities are discussing the purchase of a significant stake in Barclays. ${ }^{16}$ Another Abu Dhabi entity purchased $8.1 \%$ of the common stock of Advanced Micro Devices, a U.S. chipmaker with Defense Department contracts. ${ }^{17}$ Somewhat less controversially but no less significantly, SWFs have recently made multibillion dollar investments in U.S. investment banks such as Citigroup, Morgan Stanley and Merrill Lynch, whose capital was depleted by the meltdown in the subprime mortgage market. ${ }^{18}$ Collectively, sovereign wealth funds have

11. See, e.g., Stuart E. Eizenstat \& Alan Larson, The Sovereign Wealth Explosion, WaLl ST. J., Nov. 1, 2007, at A19 (reporting that the governments of China, South Korea, and Singapore announced plans to move up to $\$ 480$ billion in foreign-exchange reserves to riskier investments).

12. See Press Release, Norwegian Ministry of Finance, White Paper on the Government Pension Fund: Laying the Foundation for Good and Sustainable Returns (Apr. 13, 2007) available at http://www.regjeringent.no/en/dep/fin/Press-releases/2007/Layingthe-foundation-for-good-and-susta.html?id=462876. ("The Government intends to increase the equity portion of the Government Pension Fund-Global from the current 40 percent to 60 percent.").

13. See Bob Davis, China Investment-Fund Head Says Focus Is on 'Portfolios,' WALL ST. J., Feb. 1, 2008, at Al3.

14. Hot Topic: Will Overseas Funds Be a Juggernaut?, Wall ST. J., Dec. 1, 2007, at A1 1 ("The deal gives the United Arab Emirates' Abu Dhabi Investment Authority a 4.9\% stake in the company, making it one of Citigroup's largest shareholders.").

15. See Keith Bradsher, World Business Briefing, N.Y. TIMES, June 21, 2007, at C12.

16. See Press Release, Barclays, Barclays Issues Shares To China Development Bank and Temasek (Aug. 14, 2007), available at http://www.investorrelations.barclays.co.uk/ INV/A/Content/Files/140807_Announcement.pdf.

17. Abu Dhabi Buys Stake, INT'L Herald TRIB., Nov. 17, 2007, at 13.

18. See David Enrich, Robin Sidel \& Susanne Craig, How Wall Street Firms Reached Out to Asia-Now Flush with Cash, Investors Find Deals on Trophy Properties, WaLl ST. J. ASIA, Jan. 17, 2008, at 19. 
invested approximately $\$ 60$ billion in Western banks since May $2007 .{ }^{19}$

The regulatory reason for the controversy over SWFs is slightly more nuanced. We must recognize that the tension between state- and marketversions of capitalism is playing itself out in two very different kinds of equity investments. The first is acquisitions of controlling stakes in domestic companies by operating companies owned by or affiliated with foreigngovernment entities. A prominent example is the failed 2005 bid for Unocal by the China National Offshore Oil Corporation (CNOOC), an energy company controlled by the Chinese government. To finance the bid, CNOOC was to receive low- interest loans from a state-owned bank and its state-owned majority shareholder. ${ }^{20}$ Most countries already have regulatory regimes in place to screen out potentially threatening investments of this type. In the United States, for example, inbound foreign investment is governed by the Exon-Florio statute, ${ }^{21}$ most recently amended in $2007 .{ }^{22}$ Under the Exon-Florio regime, the inter-agency Committee on Foreign Investment in the United States (CFIUS) reviews all notices of pending foreign acquisitions of control over U.S. companies and can recommend to the president that specific transactions be blocked because they pose a threat to national security. ${ }^{23}$ The definition of "control" in the CFIUS regulations is quite broad. It is not a bright line majority ownership test; rather, CFIUS looks to the functional abilities of an acquirer to exercise control. ${ }^{24}$ The regulations provide that there is no control when voting securities are held "solely for purposes of investment," which is defined in circular fashion to mean that the acquirer "has no intention of determining or directing the basic business decisions of the issuer."25

CFIUS is explicitly charged with considering "whether the covered transaction is a foreign government-controlled transaction., ${ }^{26}$ Subject to a narrow exception, foreign government-controlled transactions trigger an automatic 45-day investigation and various congressional reporting requirements, and require the president to make and publicly announce the final

19. Katharina Pistor, Global Network-Finance: Understanding East-West Linkages Between Sovereign Wealth Funds and Private Banks 6-7 (Jan. 2008) (unpublished working paper, on file with Stanford Law Review).

20. See Unocal Corp., Statement on Proposed Unocal/Chevron Merger (Form 425) (Aug. 3, 2005).

21. 50 U.S.C.A. app. $§ 2170(2008)$.

22. Foreign Investment and National Security Act of 2007, PUB. L. No. 110-49, 121 Stat. 246. The Foreign Investment and National Security Act codifies and clarifies the process by which foreign acquisitions of control are processed and approved.

23. The president's power to block a transaction is found in 50 U.S.C.A. app. $\S 2170$ (d)(1) (2008). Indeed, it was the threat of invocation of CFIUS review of the CNOOC bid and concomitant political fallout that caused CNOOC to abandon its attempt to acquire Unocal. See Edmund L. Andrews, Shouted Down, N.Y. TIMES, Aug. 3, 2005, at C1 (describing process by which political opposition led to bid withdrawal).

24. 31 C.F.R. pt. 800 app. B (2008).

25. 31 C.F.R. $\S 800.219(2008)$.

26. 50 U.S.C.A. app. $\$ 2170(f)(8)(2008)$. 
decision on whether to approve or block the deal. ${ }^{27}$ Other U.S. statutes prohibit foreign ownership of controlling stakes in particular industries, such as airlines or nuclear energy. ${ }^{28}$ In other industries, such as commercial banking, the acquisition of control-by a domestic or foreign entity-subjects the acquirer to a comprehensive regulatory regime of reporting, activities restrictions, and supervision that is unworkable for all but highly specialized firms. ${ }^{29}$ Although the national regulatory mechanics differ, virtually all major countries already have regulatory protections in place to guard against threats to national interests that take the form of acquisitions of control. ${ }^{30}$

The current controversy over SWFs, and our attention here, concerns a second kind of equity investment: the acquisition of significant, but noncontrolling, stakes in domestic companies by portfolio investors affiliated with foreign governments. In other words, our focus is the type of equity investments that are not subject to the CFIUS review process. For example, all of the SWF investments noted above are of this second type, and only a small number of SWFs pursue investment strategies involving control acquisitions of foreign companies. ${ }^{31}$ At present, there is no specific national or multi-lateral regulation of portfolio investments by foreign governmental entities. Yet even a foreign entity's ostensible portfolio investments of minority stakes are said to pose a variety of problems, including most provocatively a national security concern raised by the fear of a foreign entity's potential to influence a company's actions. In response, the United States, the European Union, Germany, and the United Kingdom have all taken up the call for a regulatory response. Proposals have ranged from widespread demands for increased disclosure and transparency, to restrictions on the types of equity instruments in which SWFs may invest, to calls for multiple-round, multi-lateral negotiations. ${ }^{32}$ In particular, Australia recently adopted a set of six principles

27. 50 U.S.C.A. app. $\$ 2170(\mathrm{~b})(\mathrm{l})(\mathrm{B})(2008)$; $\$ 2170(\mathrm{~b})(1)$ (D) (mandatory 45-day investigation unless Secretary of Treasury and head of lead agency jointly determine that the transaction will not impair national security); 50 U.S.C.A. app. $\$ 2170$ (b)(3)(B) (2008) (congressional reporting); 50 U.S.C.A. app. $§ 2170(d)(2)(2008)$ (presidential decision and public announcement).

28. See 49 U.S.C.A. $\S \S 40102,41102$ (2008) (airlines); 42 U.S.C.A. $\S 2133$ (d) (2008) (nuclear power).

29. 12 U.S.C.A. $\S 1841(\mathrm{a})(2)-(3)$ (2008) (defining "control" over a bank as owning or controlling $25 \%$ or more of the voting securities or "directly or indirectly exercis[ing] a controlling influence over the management or policies" of a bank).

30. See, e.g., Cynthia Day Wallace, The Multinational ENTERPrise and Legal CONTROL: Host STATE SOVEREIGNTY IN AN ERA OF ECONOMIC Globalization (2002).

31. See Sovereign Wealth Fund Hearing, supra note 7 (stating that only eight of twenty four countries' SWFs pursue corporate acquisitions, and among these only six acquire foreign companies).

32. See e.g., Joshua Aizenman \& Reuven Glick, Sovereign Wealth Funds: Stumbling Blocks or Stepping Stones to Financial Globalization?, FRBSF ECON. LETTER (Federal Reserve Bank of San Francisco, San Francisco, Cal.), Dec. 14, 2007, available at http://www.frbsf.org/publications/economics/letter/2007/el2007-38.pdf (encouraging SWFs 
that would be applied by its Foreign Investment Review Board to SWF investments, including whether the SWF's "operations are independent from the relevant foreign government."33 Similarly, the European Commission recently recommended to the European Parliament and other European Union (EU) agencies the shape of a common EU approach to SWFs, including detailed governance and disclosure requirements. ${ }^{34}$ The international lending organizations have also taken up the call, with the IMF, for example, calling for a code of best practices for SWFs. ${ }^{35}$

A thoughtful response to the sovereign wealth fund controversy requires that we clearly recognize the tension between the two very different faces of ostensibly non-controlling equity investments by foreign government entities. Viewed from one side, these investments are simply a different means of recycling trade surpluses through the capital market. This new source of equity investments provides liquidity to the equity markets and lowers the cost of equity for private corporations, just as foreign government investment in U.S. debt instruments has reduced long-term U.S. interest rates (by an amount recently estimated as 130 basis points). ${ }^{36}$ Moreover, the growth of foreign government investments in the equity market may be less of a strategic threat than if the investments had remained entirely in U.S. government debt; equity need not be refunded. The recent capital infusions provided to U.S. financial institutions also softened the effects of the subprime mortgage crisis. ${ }^{37}$

The other face of foreign sovereign equity investments is the source of the controversy. Viewed from this side, national security concerns anchor one end of a continuum of issues concerning when the interests of a foreign government may differ from those of an ordinary shareholder. To illustrate the point, consider that critics of the Abu Dhabi SWF investment in AMD expressed concern about industrial espionage, not just national security. ${ }^{38}$ Similarly,

to invest solely in index instruments); Bob Davis, How Trade Talks Could Tame SovereignWealth Funds, WALL ST. J., Oct. 29, 2007, at A2 (urging multilateral trade negotiations); Edwin M. Truman, Sovereign Wealth Funds: The Need for Greater Transparency and Accountability (Peterson Institute for International Economics, Policy Brief PB07-6, 2007), available at www.iie.com/publications/pb/pb07-6.pdf (arguing for greater transparency).

33. Henny Sender \& Peter Smith, Australia to Step up Scrutiny of Wealth Funds, FIN. TIMES, Feb. 19, 2008, at 1.

34. Commission on the European Communities, Communication from the Commission to the European Parliament, the Council, the European Economic and Social Committee and the Committee of the Regions, A Common European Approach to Sovereign Wealth Funds, COM (2008) 115 final (Feb. 27, 2008) [hereinafter Commission on the European Communities, A Common Approach to Sovereign Wealth Funds].

35. John Burton \& Chris Giles, IMF Urges Action on Sovereign Wealth, FIN. TIMES, Jan. 24, 2008, at 4.

36. MCKINSEY \& Co., supra note 9 , at 84.

37. See Enrich, Sidel \& Craig, supra note 18.

38. See Don Clark \& Chip Cummins, AMD's Infusion from Emirate May Be Only Respite, WALl ST. J., Nov. 17, 2007, at A3 (noting company statement that "no information with national-security implications" would be involved); Richard Wray, Abu Dhabi Buys 
consider SWFs' rapid infusion of capital into U.S. commercial and investment banks in the wake of the subprime writedowns. Few domestic financial institutions provided capital. If the investment opportunity was attractive in purely economic terms, why were the SWFs the principal investors? Perhaps the investments were attractive to SWFs because they got something more than a purely financial investment. Or perhaps SWF investments were particularly attractive to the current managers of the investment banks struggling with subprime writedowns because they could act quickly and were thought unlikely either to agitate for change or to seek control, an unusual combination of characteristics for investors in companies whose operating strategies created the need for massive capital investments in the first place. ${ }^{39}$ The European Commission raises concerns that SWF investment policy "may reflect a desire to obtain technology and expertise to benefit national strategic interests, rather than being driven by normal commercial interests in expansion to new products and markets. ${ }^{\circledR 0}$ Similarly, the principles adopted by the U.S., Abu Dhabi and Singapore require that SWF investments "should be based solely on commercial grounds rather than to advance directly or indirectly the geopolitical goals of the controlling government., ${ }^{, 41}$

Efforts to diffuse this tension between the benign and threatening faces of SWF equity investments requires a strategy of regulatory minimalism, one that does not spill over beyond addressing the potential conflict of interest between the foreign government and ordinary shareholders to impair the critical capital market benefits that flow from recycling large trade deficits. This is where corporate governance enters the analysis: policing conflicts of interest among participants in the firm has always been corporate governance's forte.

We propose a simple corporate governance fix that provides such a minimalist strategy. Under this approach, the equity of a U.S. firm acquired by a foreign government-controlled entity would lose its voting rights, but would regain them when transferred to non-state ownership. The result is to separate control from investment value; the expected returns to a foreign-sovereign equity investor remain identical to those of other shareholders, yet the foreign government entities lose direct influence over management through voting. Sovereign investors with purely financial motives will still invest; the proposal does not raise the cost of their investments. Sovereigns seeking strategic benefits from equity investments, however, will find SWFs to be a less

Into U.S. Chip Firm, GUARDIAN (London), Nov. 19, 2007, at 27 (describing political worries about Arab nations investing in companies involved in sensitive areas).

39. See Homan W. Jenkins, Jr., Sovereign Wimp Funds, Wall St. J., Jan. 23, 2008, at A24 (voicing the concern that "sovereign investors may provide support for maladaptive corporatism" because they are recruited as friends of current management).

40. Commission on the European Communities, A Common Approach to Sovereign Wealth Funds, supra note 34, at 4.

41. Press Release, U.S. Treasury Dep't, Treasury Reaches Agreement on Principles for Sovereign Wealth Fund Investment with Singapore and Abu Dhabi (Mar. 20, 2008), available at $\mathrm{http}: / / \mathrm{www}$.ustreas.gov/press/releases/hp881.htm. 
attractive vehicle by which to achieve their ends. This adjustment mitigates the potential conflict of interest that animates the SWF debate without affecting the benefits that SWFs bring to the capital market.

Some may perceive our proposal as protectionist. But to do so is to misconstrue the impact of vote suspension. Vote suspension is protectionist only in the sense that it operates on the frictions between competing versions of capitalism; market-based capitalist regimes are protected against incursion by new mercantilist regimes. But unlike a truly protectionist measure designed to protect domestic companies' commercial interests rather than the integrity of the structure of a form of capitalism, our proposal would not lower investment values for foreign investors on account of their nationality or sovereign affiliation per se. Moreover, as we discuss below, we fully anticipate that other countries would respond by imposing reciprocal treatment on investment funds controlled by U.S. government entities.

Our proposal is not a perfect solution to the tensions raised by SWFs. It is under inclusive, in that influence can be exercised by means other than voting; a significant shareholder need not always cast a vote to sway management. It is also over inclusive, in that even regulatory minimalism will spill over to unintended areas. We expect that countries whose SWFs are subject to the vote suspension rule in the United States would respond in kind; thus, U.S. state investment funds such as the Alaskan Permanent Revenue Fund (among the largest SWFs in the world) may be treated reciprocally by other countries. ${ }^{42}$ Despite its imperfections, vote suspension does serve to constrain a major source of concern over SWF investment without creating a barrier to recycling trade surpluses.

To be sure, vote suspension does not address the more deeply rooted and significant frictions that arise from the interactions of different capitalist systems, which do involve issues of real protectionism. However, it does effectively address the high profile concern over SWFs that, left unaddressed or addressed too broadly, has the potential to disrupt seriously the global capital market through heavy-handed regulation and protectionism.

Part I describes the SWF phenomenon with a focus on the significant changes that have propelled these institutions to the forefront of debate in the global capital markets: their rapid growth and recent shift in investment strategy. Part II explores the two faces of SWF equity investments-one benign, the other threatening. The benign face is the prosaic desire of any investor to achieve higher returns and greater diversification, particularly in response to changes in the global markets and increasing liabilities resulting from demographic trends. The threatening face is the possibility that SWFs may invest for strategic rather than purely investment motives, raising the

42. Although it does not share some of the key characteristics of a sovereign wealth fund, we expect that even CalPERS could be subject to reciprocal treatment abroad. For further discussion, see infra Part IV.B. 
specter of national security threats, industrial espionage, and similar harms to core interests of any sovereign state. Disentangling these two faces provides a better perspective from which to craft a response to the SWF controversy. In Part III, we present our minimalist solution-vote suspension for SWF equity investments. We explain why this solution responds to the potentially threatening side of SWF investments while leaving the benign face undisturbed. Part IV examines the limitations of our solution, and explains why these limitations are outweighed by the benefits of vote suspension. We then conclude.

\section{THE SOVEREIGN WEALTH FUND PHENOMENON}

Despite the recent explosion of attention and concern, the earliest sovereign wealth funds are more than 50 years old and, until recently, have operated in relative obscurity. But while these are not new institutions in global finance, the economic landscape in which they operate has changed in two dramatic ways. The first is the size of the phenomenon, as SWFs have grown and proliferated in recent years. The second change involves a shift in their investment strategy, from sovereign debt to corporate equity. In this Part, we explore the SWF phenomenon and the recent transformations that have brought them to the world's attention.

Like some other entities active in global finance such as hedge funds, sovereign wealth funds defy attempts at straightforward definition. In essence, they are equity investment vehicles established by and under the control of sovereign states. The key characteristic is government ownership of the fund, but this characteristic is shared by a host of other entities. Sovereign wealth funds belong to a continuum of sovereign investment vehicles. ${ }^{43}$ At one end of the spectrum are central banks. At the other end are state-owned enterprises such as Russia's Gazprom or China's National Offshore Oil Corp. In between are sovereign stabilization funds, sovereign saving funds, and government investment corporations. Thus, one way to define sovereign wealth funds is by exclusion: SWFs are sovereign investment vehicles that are not central banks, monetary authorities in charge of foreign reserves, or national pension funds, unless they are financed by commodities exports. ${ }^{44}$

Sovereign wealth funds are typically grouped according to the source of their assets. Most sovereign wealth funds are financed by the sale of commodities, especially oil. Prominent examples include the Norway

43. Cittigroup Global Markets Inc., Sovereign Wealth Funds: A Growing GLOBAL FORCE 11 (2007).

44. Gerard Lyons, Standard Chartered Bank, State Capitalism: The Rise of SOVEREIGN WEALTH FUNDS 3 (2007). National pension funds are included in the definition of SWF only if they are financed directly by foreign-exchange assets generated by commodity exports. This excludes, for example, Chile's Pension Guarantee Fund, but includes Norway's Government Pension Fund-Global. 
Government Pension Fund and the various Middle Eastern SWFs. Noncommodity funds are typically established through transfers of assets from foreign-exchange reserves generated by trade surpluses. The China Investment Corporation is the most prominent example.

Just as it is difficult to provide a precise definition of SWFs, it is difficult to generalize about their objectives and investment policies. The objectives of the funds may include stabilization of the macroeconomic effects of sudden increases in export earnings, the management of pension assets or a separate tranche of foreign-exchange reserves, or the intergenerational transfer of wealth. The assets may be managed directly by an agency of the government, or management may be subcontracted out to professional managers within or outside the country. Sovereign wealth funds invest broadly across asset classes and differ in their investment strategies. Some are broadly diversified and only hold small stakes in any one firm. Some take small stakes to avoid disclosure requirements. A minority of SWFs acquire significant stakes in domestic and foreign companies. Others, of less interest for our purposes, invest only in sovereign bonds. The level of transparency also differs significantly. The Norway Government Pension Fund provides full disclosure of its portfolio and investment policies. ${ }^{45}$ Most SWFs, on the other hand, provide virtually no public disclosure. Transparency varies even within funds controlled by the same sovereign. Singapore's Temasek publishes an annual report, while the Singapore Government Investment Corporation provides no public disclosure ${ }^{46}$ Chart 1 maps the investment approach and transparency of the top twenty SWFs.

45. See Norges Bank, Norges Bank Investment Management, available at http://www.norges-bank.no/Pages/Article_41394.aspx (listing fund strategy, a benchmark portfolio, ethical guidelines and other fund information); see also Kristin Halvorsen, Comment, Norway's Sovereign Fund Sets an Ethical Example, FIN. TIMES, Feb. 15,2008 , at 9 (by Norway's Minister of Finance).

46. See Burton \& Giles, supra note 35 (calling the GIC one of the "most secretive" of the SWFs). 
CHART 1: TRANSPARENCY AND INVESTMENT APPROACH OF THE TOP TWENTY SOVEREIGN WEALTH FUNDS

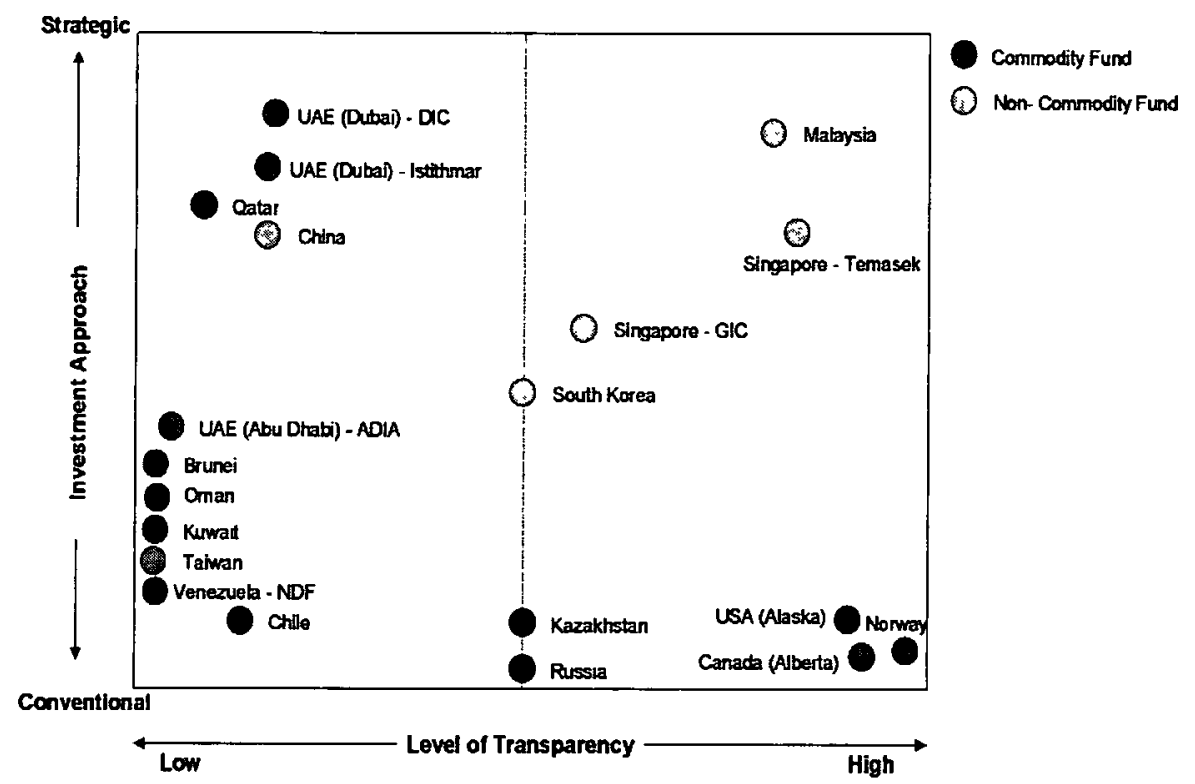

Source: Gerard Lyons, STANDARD Chartered BanK, State Capitalism: THe Rise of SOVEREIGN WEALTH FUNDS 8 (2007).

The numbers, size and prominence of SWFs in global capital markets have expanded exponentially in the past few years. Today, the estimated assets under management for the top twenty SWFs amount to over $\$ 2$ trillion, and the total value of assets managed by SWFs equals almost half the market capitalization of the Tokyo Stock Exchange. ${ }^{47}$ Collectively, SWF-managed assets roughly equal those in hedge funds and private equity funds combined. The current $\$ 2.2$ trillion in SWFs compares with about $\$ 1-1.5$ trillion in hedge fund assets and about $\$ 0.7-1.1$ trillion in private equity. ${ }^{48}$ The five largest SWFs are ADIA from the United Arab Emirates, Norway's Government Pension Fund, Singapore's Government Investment Corporation (another Singapore fund, Temasek, is in the top ten), the Kuwait Investment Authority, and the China Investment Corporation. Each of these funds, as well as Temasek and Russia's Stabilization Fund, has assets in excess of $\$ 100$ billion. Table 1 lists the twenty largest SWFs and their estimated assets.

47. LYONS, supra note 44 , at $6 \& 17$ chart 3.

48. Id. at 6 . 
TABLE 1: ESTIMATEd Size OF SOVEREIGN WEALTH FUNDS

(IN BILLIONS OF U.S. DOLLARS)

\begin{tabular}{|c|c|c|c|c|}
\hline Country & $\begin{array}{l}\text { Fund } \\
\text { Name }\end{array}$ & $\begin{array}{l}\text { Launch } \\
\text { Year }\end{array}$ & $\begin{array}{c}\text { US\$ } \\
\text { billion (1) }\end{array}$ & $\begin{array}{c}\% \text { of } 2006 \\
\text { GDP }\end{array}$ \\
\hline $\begin{array}{l}\text { UAE } \\
\text { (Abu Dhabi) }\end{array}$ & ADIA & 1976 & 625.0 & $520.7 \%$ \\
\hline Norway & $\begin{array}{l}\text { Governmental } \\
\text { Pension Fund- } \\
\text { Global }\end{array}$ & 1990 & 322.0 & $102.6 \%$ \\
\hline Singapore & GIC & 1981 & 215.0 & $169.0 \%$ \\
\hline Kuwait & $\begin{array}{l}\text { Kuwait } \\
\text { Investment } \\
\text { Authority }\end{array}$ & 1953 & 213.0 & $268.7 \%$ \\
\hline China & $\begin{array}{l}\text { China } \\
\text { Investment } \\
\text { Corporation }\end{array}$ & 2007 & 200.0 & $8.0 \%$ \\
\hline Russia & $\begin{array}{l}\text { Stabilization } \\
\text { Fund }\end{array}$ & 2004 & 127.5 & $14.2 \%$ \\
\hline Singapore & Temasek & 1974 & 108.0 & $84.9 \%$ \\
\hline Qatar & $\begin{array}{l}\text { Qatar } \\
\text { Investment } \\
\text { Authority }\end{array}$ & 2005 & 60.0 & $185.3 \%$ \\
\hline US (Alaska) & $\begin{array}{l}\text { Permanent } \\
\text { Reserve Fund }\end{array}$ & 1976 & 40.2 & $0.3 \%$ \\
\hline Brunei & $\begin{array}{l}\text { Brunei } \\
\text { Investment } \\
\text { Authority }\end{array}$ & 1983 & 30.0 & $309.4 \%$ \\
\hline Korea & $\begin{array}{l}\text { KIC (Korea } \\
\text { Investment } \\
\text { Corporation) }\end{array}$ & 2005 & 20.0 & $2.2 \%$ \\
\hline Malaysia & $\begin{array}{l}\text { Khazanah } \\
\text { Nasional BHD }\end{array}$ & 1993 & 17.9 & $12.3 \%$ \\
\hline Venezuela & $\begin{array}{l}\text { National } \\
\text { Development } \\
\text { Fund (Fonden) }\end{array}$ & 2005 & 17.5 & $10.5 \%$ \\
\hline $\begin{array}{l}\text { Canada } \\
\text { (Alberta) }\end{array}$ & $\begin{array}{l}\text { Alberta } \\
\text { Heritage } \\
\text { Savings } \\
\text { Trust Fund } \\
\end{array}$ & 1976 & 16.4 & $1.3 \%$ \\
\hline Taiwan & $\begin{array}{l}\text { National } \\
\text { Stabilization } \\
\text { Fund }\end{array}$ & 2001 & 15.2 & $4.0 \%$ \\
\hline Kazakhstan & National Fund & 2000 & 14.9 & $15.6 \%$ \\
\hline Chile & Economic and & 2006 & 9.7 & $7.6 \%$ \\
\hline
\end{tabular}




\begin{tabular}{|l|l|c|c|c|}
\hline & $\begin{array}{l}\text { Social } \\
\text { Stabilization } \\
\text { Fund }\end{array}$ & & & \\
\hline UAE (Dubai) & Istithmar & 2003 & 8.0 & $6.7 \%$ \\
\hline UAE (Dubai) & DIC & 2004 & 6.0 & $4 / 0 \%$ \\
\hline Oman & $\begin{array}{l}\text { State General } \\
\text { RF }\end{array}$ & 1980 & 6.0 & $16.0 \%$ \\
\hline Total & & & 2,072 & \\
\hline
\end{tabular}

Source: Gerard Lyons, Standard Chartered BanK, State Capitalism: THE Rise of SOVEREIGN WEALTH FUNDS 15 (2007).

The sudden emergence and growth of SWFs as players in the global capital markets are due to several interrelated factors. One is the spike in world oil prices, which has brought massive revenues to oil exporters such as Norway, Russia, and the Middle East. A second factor is the enormous accumulation of foreign-exchange reserves by Asian central banks, a portion of which has been split off and invested separately in SWFs. Official foreign-exchange reserves for the seven major Asian central banks at the end of 2006 were $\$ 3.1$ trillion. ${ }^{49}$ These accumulations stem in significant measure from the current-account deficit run by the United States, and have been fuelled in certain cases by exchange rate management. Some Asian central banks-most controversially the People's Bank of China-have intervened in the foreign-exchange markets to preserve the competitiveness of their country's exports, buying dollars and other foreign currencies while selling domestic currencies. This practice has been dubbed the "Bretton Woods II" system because some economies have effectively pegged their currencies to the dollar. ${ }^{50}$

Analysts predict that SWFs will continue to grow significantly in the coming years, due to continuation of the same factors that sparked their growth over the past decade. These include unrestricted international flows of capital, predicted trends in commodities prices and foreign-exchange reserves, continued high growth in transition economies, demands on the public pension systems of aging societies, and high internal rates of return on the funds themselves. One analyst calculates that if recent growth rates are repeated over the next decade, total funds under SWF management will reach $\$ 13.4$ trillion. $^{51}$ The IMF estimates that the aggregate foreign assets under sovereign management could grow to about $\$ 12$ trillion by $2012 .^{52}$ Of course, whether these figures are large or small obviously depends on the metric by which they are measured. ${ }^{53}$ Currently, the largest SWFs, those from the United Arab

49. MCKINSEY \& CO., supra note 9, at 73.

50. Id. at 77 .

51. LYONS, supra note 44 , at 5 .

52. Id. at 6.

53. See Kimmitt, supra note 4. 
Emirates, Kuwait, Norway, and China, have reached the same scale as the largest global asset managers, hedge funds, and private equity funds in the world. ${ }^{54}$ By any measure, as a senior U.S. Treasury official recently noted, "SWFs are already large enough to be systemically significant[, and] they are likely to grow larger over time ....."55

At the same time as their assets have grown, SWFs have shifted their investment strategy toward equity in order to diversify away from relatively low-return, U.S. dollar-denominated assets-particularly U.S. government treasury securities. Until recently, such assets have been the mainstay of Asian central bank reserve investments. As of November 2006, for example, China held about $\$ 347$ billion in U.S. treasuries and as of September 2006 the Asian central banks collectively held a third of total U.S. government debt outstanding. ${ }^{56}$ The decline of the dollar vis-à-vis the euro and other major currencies has reduced the attractiveness of dollar-denominated financial instruments to foreign holders. Moreover, the quest for higher returns, common to all investors, is made more acute by demographic trends in many reserverich countries. Aging societies in East Asia, for example, will place huge financial burdens on their national public pension systems because in the coming decades fewer workers will be supporting more retirees. To help bridge the shortfall, planners must seek higher returns on publicly held retirement assets.

A final factor influencing the recent formation and investment strategies of SWFs is that success breeds imitation. Some government investment funds, particularly Singapore's Temasek Holdings, have proven to be capable activist investors. Temasek, founded in 1974, is a holding company for Singaporean state-owned enterprises (SOEs) and government-linked corporations. It has served as a role model for newly established funds in East Asia, and has been suggested as a useful template for corporate governance of Chinese SOEs. ${ }^{57}$ Norway's Government Pension Fund, one of the oldest and most professionally managed of the SWFs, is also held up as an example of sound public stewardship of investment assets. ${ }^{58}$ Again, this phenomenon is not unique to the world of SWFs. Just as the California Public Employee Retirement System (CalPERS) became a role model for activist public pension funds in the United States, governments around the world are seeking to emulate the success of the Singaporean and Norwegian funds in managing public money. ${ }^{59}$

54. Citigroup Global Markets, INC., supra note 43, at 13.

55. Kimmitt, supra note 4.

56. MCKINSEY \& Co., supra note 9, at 71.

57. Lay-Hong Tan \& Jiangyu Wang, Modelling an Effective Corporate Governance System for China's Listed State-Owned Enterprises: Issues and Challenges in a Transitional Economy, 7 J. CORP. L. STUD. 143, 172 (2007).

58. See supra note 45 and accompanying text.

59. See Emma Charlton, Norway's Sovereign Fund Serving as Model, WaLL ST. J., Nov. 19, 2007, at C7; Raphael Minder, ADB Calls for Transparency of Asia Funds, FIN. 


\section{TWo FACES OF SWF EQUITY INVESTMENTS}

On first impression, it may be hard to understand why non-controlling equity investments by SWFs are controversial. The benefits are straightforward. Equity investments serve to recycle trade surpluses and to increase the supply of funds to the equity market, reducing the cost of capital, just as foreign government investment of foreign reserves in U.S. government debt instruments has reduced interest rates in the United States. Equity investment, as compared to investment in debt, is also more stable, in that its withdrawal is less disruptive than withdrawal from the debt market. ${ }^{60}$ Indeed, because equity investments reflect long-term values, these investments leave SWFs hostage to the health of the economies in whose corporations they invest. Unlike government debt, the SWFs cannot hold equity investments until they mature and decline to reinvest. Rather, equity investments must be sold to a willing buyer in light of any change in circumstances, including the actions of the particular sovereign; SWFs, and their governments, bear the cost of any decline in equity value. Thus, increased equity investments by new mercantilist-regime SWFs are arguably a better means of recycling funds between state and market capitalism than sovereign debt investments. Finally, SWFs supply a source of liquidity in circumstances where it may be greatly needed. SWF investments in U.S. commercial and investment banks following the depletion of their capital as a result of the subprime debt crisis-for example, in Citigroup, Bear Stearns, Merrill Lynch, and Morgan Stanleyprovided needed capital that otherwise may not have been readily available.

So where do the problems lie? Judging from the terms of the public controversy provoked by SWFs, the principal though hardly sole danger comes from lack of transparency. Some of the SWFs making the highest profile equity investments, such as those of Abu Dhabi, Qatar, and China, provide very little public information about their investment strategies and holdings, in contrast to the Norwegian fund, which provides annual reports disclosing both. ${ }^{61}$ SEC Chairman Cox has recently suggested that the lack of transparency of SWFs may mask market abuses such as insider trading, ${ }^{62}$ which if widespread could raise the cost of capital by undermining investor confidence in the market. But

TIMES, Nov. 26, 2007 (quoting Asian Development Bank as acknowledging that Singapore "set[] the pace in Asia" and touting Norway as the best model to emulate); $c f$. Sovereign Wealth: A Code of Conduct Is Needed For Both Funds and Recipients, FIN. TIMES, Jan. 28, 2008 , at 8 (noting that International Monetary Fund has asked these governments for help in drawing up disclosure guidelines).

60. See Congressional Research Service, supra note 10, at 45 ("[T]here is a legitimate concern that financial markets would be disrupted" if the Chinese dump their holdings of U.S. Treasuries on the market.). text.

61. LyONS, supra note 44 , at $20-21,24,27$; see also supra note 45 and accompanying

62. See Kara Scannell, Cox Cites Concerns over Sovereign Funds, WALL St. J., Oct. 25,2007 , at $\mathrm{A} 8$. 
regardless of how many times it is invoked, the lack of transparency cannot itself be the problem, and as a result greater transparency cannot itself be the solution.

The fact is that all shareholdings are nontransparent unless a particular jurisdiction imposes a disclosure obligation. For example, U.S. securities regulation requires prompt disclosure of the identity of five-percent shareholders in public companies and of those who seek to influence control through a proxy fight or tender offer, as well as periodic disclosure of mutual fund holdings. ${ }^{63}$ Additionally, an equity sale by a public company of a significant equity stake, even if less than five percent, must be promptly disclosed. ${ }^{64}$ This was the case with the Abu Dhabi SWF investment in Citigroup. However, there is no general disclosure requirement for shareholders that hold less than five percent of a company's equity. As a result, the equity holdings of most hedge funds, for example, are no more transparent than those of SWFs. Disclosure regulations in the European Union and major Asian countries are roughly similar. To explain the controversy, SWFs must pose different problems than other nontransparent shareholders. The prompt public disclosure of the terms of the Abu Dhabi SWF's investment in Citigroup did not temper the Wall Street Journal's editorial concern over what the newspaper styled as "Citi of Arabia." 65

The economic logic of public corporations highlights a problem that does distinguish SWFs from other nontransparent shareholders. In a widely held public corporation, shareholders' wealth is not affected by the corporation's performance other than through the value of the corporation's shares, a condition that results from shareholders holding diversified portfolios in an efficient capital market. In that circumstance, all shareholders will agree that the company should maximize the value of its shares (although they may still differ over how this is best accomplished)-what economists call the "unanimity principle." However, this shared commitment to profit maximization will not hold if a shareholder can gain from the corporation's activities in ways that other shareholders cannot. For example, a shareholder who owns a tavern across the street from one of the corporation's factories will have a different view about closing that plant than other shareholders; the tavern owner may oppose the plant closing even if closing the plant is best for the corporation. In this vein, an SWF may have a strategic motive in addition to, or instead of, an investment motive. The SWF may wish to help domestic

63. Securities Exchange Act of 1934, $\S 13(d)$, (f), 15 U.S.C. $\S 78 \mathrm{~m}(\mathrm{~d})$, (f) (2000) (reports upon acquiring $5 \%$ ownership and reports by institutional investors); Securities Exchange Act of 1934, $\S 14(a)$, (d), 15 U.S.C. $\S 78 \mathrm{n}(\mathrm{a})$, (d) (2000) (reports in connection with proxy solicitations and tender offers).

64. See Exchange Act Rule 13a-11, 17 C.F.R. § 240.13a-11 (2008); Sec. \& Exch. Comm'n, Form 8-K, General Instructions, available at http://www.sec.gov/about/forms/ form8-k.pdf.

65. Editorial, Citi of Arabia, WALL St. J., Nov. 29, 2007, at A18. 
companies secure technology or other expertise from a portfolio company even if that transfer reduces the portfolio company's value-the loss to the portfolio company is shared by all owners, while the benefit from the transfer accrues entirely to the SWF and its government. A fair reading of the current SWF debate strongly suggests that the principal concern with SWF equity investments is that they may have a significant strategic element driven by selfinterest. The fear is that SWFs will use their influence on portfolio companies to secure technology (a concern raised explicitly in the discussion of the Abu Dhabi fund's investment in AMD), gain access to natural resources, or improve competitive positions for domestic companies, potentially in a fashion that has national security concerns for the portfolio company's country of incorporation. ${ }^{66}$ To be sure, no one can point to a reported incidence of such behavior. However, the debate takes the potential (and the logic) for such behavior extremely seriously.

\section{A Minimalist SOLUTION: VOTE SUSPENSION}

If the problem with SWF investments is that some funds have strategic, rather than investment motives, or have the potential to support strategic behavior should circumstances change in the future (in effect, strategic option value), then the appropriate response is quite straightforward, at least at the conceptual level: constrain strategic investments, but leave traditional investments unaffected. With respect to traditional investments, SWFs' interests and contributions are identical to those of other shareholders, and they also provide the range of important macroeconomic benefits we canvassed earlier. Thus, the line to walk is clear. The question is whether it is feasible.

Actually designing such minimalist regulation is greatly complicated by the fact that an SWF's investment motives are not transparent regardless of the extent of an SWF's formal disclosure--its public statements, reports, or filings. Suppose that pursuant to a new regulatory requirement of an NGO-promulgated code of best practices, an SWF states that it operates entirely independently of its government owner. Why would anyone believe the statement? Even if true in the past, it will be true in the future only if the government so chooses-the strategic optionality point. Could anyone genuinely believe that the investment managers of China Investment Corporation or Singapore's Temasek would hang up the phone if a senior government (or in China's case, Party) official called to offer advice on the fund's handling of a particular investment to advance the country's, rather than the portfolio company's, interests? ${ }^{67}$ Again,

66. The European Commission's recent recommendation to the European Parliament and the U.S.-Singapore-Abu Dhabi principles provide a representative list of concerns. See supra notes 34 and 41 and accompanying text.

67. We do not mean to single out specific foreign governments or foreign governments in general as having great influence vis-à-vis economic actors. All governments have such influence. Recall that only one U.S. telecommunications company refused to comply with a 
transparency, whether mandated or encouraged through codes of best practices - the ubiquitous current policy response to concerns about SWFsdoes not address the real problem. ${ }^{68}$ Additional disclosure simply cannot distinguish between strategic and non-strategic investors.

Finally, a disclosure response runs the risk of putting off the government owners of SWFs, and potentially shifting investments away from developed countries, even though the approach is likely ineffectual. The governance principles the United States, the EU, and the IMF seek to impose on SWFs go directly to a government's power to manage its own assets and entities. Calling the proposed codes voluntary is somewhat misleading. The European comply or disclose approach, from which the SWF disclosure approach is derived, assumes that the market will enforce the voluntary standards if a company does not comply. But when the noncomplying party is an SWF, the only feasible enforcement agent is the portfolio company's government. Thus, either the proposed codes are entirely unenforceable, or they result in a direct intrusion on the sovereignty of the SWF's government owner.

This leads us to a response that focuses on corporate governance. The corporate governance system represents the complex of mechanisms by which a corporation makes decisions. They include management practices and organizational routines, as well as the formal procedures specified in state corporation statutes and elaborated in judicial decisions by the courts in the corporation's state of incorporation. Thus, the corporate governance system also represents the structure through which an SWF investor must channel its efforts to influence the corporation in its portfolio to act in the SWF's interests, as opposed to those of the corporation.

In important circumstances, the formal elements of corporate governance have great importance. Even the informal, nonlegal elements can operate in the shadow of the formal, legally dictated decision structures. Suppose a corporation's senior executives resist efforts by a significant SWF shareholder to influence the corporation's decisions in a fashion favorable to the SWF, for example, by declining to authorize technology transfer arrangements with corporations in the SWF's jurisdiction. In that event, the SWF shareholder can seek to have the board of directors replace the recalcitrant managers. If that

request by the National Security Agency to turn over phone call records of their customers in the interests of national security-a request with a questionable legal foundation and concerning which Congress was unsuccessfully asked to provide retroactive immunity. The three largest telecommunications companies turned over the call histories of their customers without objection. See Leslie Cauley, NSA Has Massive Database of Americans' Phone Calls, U.S.A. TODAY, May 11, 2006, at 1A.

68. For example, a senior U.S. Treasury official lists five policy principles that should be followed by SWFs. Among these, the first is that SWFs should invest commercially, not politically. The second is that SWFs should be transparent about their investment policies as a means of conveying world-class investor integrity. Kimmitt, supra note 4 . While these are completely laudable goals, a commitment by an SWF to abide by these principles is not credible because there is no mechanism that bonds the SWF to its promise. 
fails, the SWF can seek to persuade other shareholders to join with it and replace the board. Thus, an SWF's informal influence depends, ultimately, on its formal influence-its ability to vote its shares.

If an SWF shareholder's influence depends on its ability to vote its shares, then the obvious means to prevent strategic behavior-behavior that benefits the SWF or its sovereign owner in ways that do not proportionately benefit other shareholders-is to restrict an SWF's right to vote. Shares of U.S. companies acquired by an SWF would lose their voting rights (or automatically be voted in the same proportion as the votes of non-SWF shareholders). ${ }^{69}$

Of course, the expected objection to eliminating the voting rights of SWFheld shares is that it will reduce the shares' value - non-voting shares are worth less than voting shares. It is this observation that fuels the ultimately mistaken view that our proposal is protectionist because it reduces the value of foreign SWF shares. The problem is exacerbated because an SWF's motives for investing cannot be accurately observed; without more, the proposal does not successfully walk the line between strategic and non-strategic investors. Because a statement by the SWF that it operates independently of its government owner or that it has only non-strategic investment motives is not credible, the loss of voting rights must apply to all SWFs, even if most SWFs in fact have solely traditional investment motives (or the value of the strategic option to the particular SWF-say Norway-is small). The result, the argument runs, will be to discourage all SWFs from investing, not just those with the feared strategic motives; all SWFs will have to pay the higher price of voting shares, but will receive only lower-value, non-voting shares. One would expect that the important beneficial aspects of SWF capital recycling then would be compromised. This is hardly regulatory minimalism, and our proposal would not be a workable solution if it ended there.

This problem of overinclusion can be solved if the voting rights of SWFheld shares are only suspended. The second half of our proposal is that the shares regain their voting rights when they are sold by the SWF to a nongovernmentally affiliated third party. Under our proposal, an SWF buys voting shares and sells voting shares. Therefore, it would not affect the SWF's ability to sell voting stock into the market, tender voting shares in a tender offer, or sell a block of voting stock to a willing purchaser ${ }^{70}$ The loss of voting rights

69. Note the rough inverse parallelism with the "break through rule" of the EU Takeover Directive. Under the Directive, shareholder-voting restrictions provided by corporate charter or contract do not apply where the offeror has gained $75 \%$ of the shares of the target. That is, under certain conditions, non-voting shares become voting shares. Council Directive 2004/25, art. 11, 2004 O.J. (L 142) 12.

70. Thus, the influence of SWF holdings in control transactions and the market for corporate control would not be compromised. SWF shares would become voting if purchased by, for example, a hostile bidder for a portfolio company. Our vote suspension regime would not apply if the SWF acquired sufficient shares to achieve control (again, a reverse break-through rule). That acquisition would be subject to CFIUS review, thereby 
while the SWF holds the shares-that is, the SWF's loss of the ability to use the formal and informal mechanisms of corporate governance to serve strategic ends - serves only to separate those SWFs with strategic motives, whose investment should be discouraged, from SWFs with purely investment motives, whose investment should be encouraged. Most important from the perspective of regulatory minimalism, eliminating the voting rights of SWF-held shares does not require an administrative determination of an SWF's investment motives, which would carry with it the obvious discomfort of requiring sovereign governments to defend their capital market transactions in a proceeding conducted by another government. Rather, voting suspension results in self-enforcement by the SWFs themselves because the rule generates a separating equilibrium: those SWFs for whom strategic value is important simply will not invest, while those SWFs which, like other shareholders, are interested only in investment value, will not be deterred. ${ }^{71}$ And unlike the proposed codes of best practices, vote suspension does not presume to impose restrictions on how a sovereign government manages its assets or entities.

\section{THE LIMITS OF VOTE SUSPENSION}

Suspending the voting rights of SWF-held shares, while reflecting a minimalist approach to regulation, is not entirely successful in eliminating regulatory clutter; it is nonetheless both under and over inclusive. The underinclusion is the more important, although its effects are less politically charged than the effects of overinclusion. On balance, neither underinclusion nor overinclusion presents a significant counterweight to the self-enforcing character of vote suspension.

\section{A. The Problem of Underinclusion}

The most significant way in which suspending the voting rights of SWFheld shares is under inclusive results from the simple fact that using the formal corporate governance system to influence a portfolio company's decisionmaking, whether directly or indirectly, is not the only way an SWF can seek to secure a strategic advantage from a portfolio firm. In addition, an SWF is not the only vehicle through which a government can act strategically to influence a foreign corporation's decisions.

eliminating the need for vote suspension since the approval process addresses strategic concerns directly.

71. More precisely, the vote suspension rule operates as a kind of forcing contract that results in a separating equilibrium-one in which SWFs with non-strategic motives continue to invest and those with strategic motives do not-without further government action. The success of the effort depends on the strategically motivated investors having alternative investments-like controlling acquisitions-that are more attractive to them because of their strategic value, but which will not be more attractive to non-strategic investors. 
Even if the voting rights of SWF-held shares are suspended, the SWF still may be able to influence strategically the portfolio company's decisions to the extent that the portfolio company hopes for future capital infusions from the SWF; simple reciprocity can operate without the SWF having to invoke the portfolio company's formal governance structure because the future also casts a shadow. So long as the portfolio company knows what the SWF wants, the portfolio company's desire for future equity capital on favorable terms may allow the SWF to influence the portfolio company's behavior despite its lack of voting rights.

While this concern cannot be dismissed entirely, constraints exist that cabin this kind of strategic tit-for-tat. Most important, the generally applicable disclosure requirements governing public corporations in developed economies will provide a level of transparency that constrains the portfolio company's freedom to secure future capital by advancing the SWF's strategic interests. In most developed economies, the new issuance of shares of a magnitude large enough to support reciprocity will trigger disclosure of the issuance by the portfolio company. Such disclosure of the SWF's interests alerts other large shareholders, as well as the domestic government, to the risk of strategic influence.

It is also likely that existing generally applicable corporate disclosure rules will mandate portfolio company disclosure of commercial transactions of a size large enough to advance significantly the interests of the SWF's government. For example, in the United States a material transaction between the portfolio company and a government-controlled company likely would require explicit disclosure by the portfolio company as part of its continuous disclosure obligation under U.S. securities laws. That disclosure, in turn, could also lead to state corporate law enforcement of rules governing self-interested transactions. ${ }^{72}$

To be sure, one could imagine an SWF initiating a reciprocal exchange not by buying new shares, but by buying shares in the secondary market with the goal of artificially supporting the portfolio company's stock price and, therefore, reducing its cost of new capital from others. But this pattern presents a disclosure problem as well. Issuing new capital to the public at the SWFsupported price will require that the portfolio company disclose the expected reciprocity (if the company does not know the strategy, reciprocity is impossible), which will operate to dissipate the effect of the price support. A failure to disclose the expected reciprocity will subject portfolio-company managers to enforcement actions. While the suspended vote is conceptually under inclusive, in operation the extent of the problem is likely small.

Perhaps more important than reciprocity between an SWF and a portfolio company, a foreign government can act strategically with respect to a particular

72. See, e.g., PRINCIPles of Corporate Governance: Analysis AND RECOMMENDATIONS pt. V (1992). 
company through entities other than an SWF. In countries with large SWFs, governments typically own significant stakes in operating companies. China and Singapore are familiar examples. A government-controlled operating company may have the power to secure strategic concessions from a foreign company as a precondition to the government company's commercial purchases from the foreign company or as the price of market entry through a joint venture. Suspending the voting rights of SWF-held stock affects none of these techniques because these are not SWF-related relationships. They result not from the government's role as investor, as with an SWF, but from the government's role in state capitalism. The difficulties caused by the plate tectonics between capitalist systems in which the government plays radically different roles are far more important and far more complicated that those associated with SWFs. Suspended voting addresses only the latter.

The last of the areas of underinclusion, and we think the least important, is an SWF's ability to acquire voting rights independently of its actual share ownership, through what has come to be called "empty voting"- the acquisition of voting rights without the associated equity ownership (the reciprocal of suspending the voting rights of SWF-held stock). This is accomplished by the SWF (or any other government controlled entity) securing voting rights without an equity investment through borrowing shares, hedged investments, or custom derivatives. ${ }^{73}$ In the limited circumstances where these techniques have been observed, the company typically is not willing to cooperate with the party seeking to influence the company's behavior. ${ }^{74}$ The debate over SWFs, in contrast, is largely over cooperative arrangements, where the SWF's investment is desired by the company. In a non-cooperative circumstance, efforts to avoid the voting suspension can be detected by the portfolio company and can be challenged under state corporate law. While theoretically possible, we do not view empty voting techniques as being a significant factor in the SWF debate.

\section{B. The Problem of Overinclusion}

Suspending the voting rights of SWF-held equity is also over inclusive because it will impact entities other than foreign SWFs. To this point, our discussion has treated equity investments by SWFs and government pension funds as creating equivalent risks of strategic behavior. For the purpose of assessing overinclusion, the role of government pension funds takes on special

73. See Henry T.C. Hu \& Bernard Black, The New Vote Buying: Empty Voting and Hidden (Morphable) Ownership, 79 S. CAL. L. REV. 811 (2006); Henry T.C. Hu \& Bernard Black, Equity and Debt Decoupling II: Importance and Extensions (U. Tex. Sch. of Law, Law \& Econ. Research Paper No. 122) available at http://papers.ssrn.com/sol3/papers.cfm? abstract_id=1030721.

74. See, e.g., Marcel Kahan \& Edward B. Rock, Hedge Funds in Corporate Governance and Control, 155 U. PA. L. REV. 1021, 1075-77 (2007). 
prominence. From the perspective of the United States, the overinclusion problem results from the expectation that governments whose SWFs and pension funds have their voting rights suspended will impose similar suspensions on the equity holdings of comparable U.S. government entities. Unless the U.S. Social Security System is reorganized to allow it to make equity investments, as the Bush administration unsuccessfully proposed, the impact of this reaction will fall almost exclusively on state pension funds, like CalPERS, and the few U.S. state-level SWFs, like the Alaska Permanent Revenue Fund, all of which hold increasing amounts of foreign equities for the same reason that investment-oriented foreign SWFs have shifted to equity investments-to increase their returns and diversification.

On first consideration, suspending the voting rights of U.S. state pension fund foreign-equity investments should not hurt the funds' performance for the same reason that vote suspension should not deter U.S. equity investments by foreign SWFs who do not have a strategic motive. As long as the U.S. state pension funds are treated in reciprocal fashion-that is, suspended voting rights are restored when the shares are sold--the holding-period suspension does not reduce the shares' investment value. On further consideration, however, something is lost: the positive impact that shareholder activism by U.S. state pension funds, most vocally by CalPERS, has had on corporate governance standards in other countries. ${ }^{75}$ This effort, which is not strategic because all shareholders benefit equally from it, does require voting rights. Its loss will be felt not only by the U.S. funds with respect to their existing investmentsfuture investments will be at prices that reflect the loss of pressure for good governance - but also by other companies selling equity in those markets, where a reduction in the pressure for more effective corporate governance can be expected to increase the cost of capital. An optimistic view is that the cost will be relatively small. The successful movement toward higher corporate governance standards across the developed world makes the role U.S. state pension funds have played less central to the effort to improve corporate governance standards. To be sure, this is a cost, but we think not a large one.

\section{CONCLUSION}

The high profile controversy over SWFs' shift to equity investments is only one of the frictions that result from the interaction of two very different conceptions of the role of government in a capitalist economy. But because this form of portfolio investment in private firms by government-controlled funds, unlike investments of controlling stakes by SOEs, currently falls outside

75. See Cal. Pub. Employees' Ret. Sys., Global Principles of Accountable CORPORATE GOVERNANCE 13 (2007), available at http://www.calpersgovernance.org/principles/international/global/downloads/global-corpgov-principles.pdf (describing policies for developing nations and other countries). 
national regulatory regimes, it has raised considerable concern over a potential loss of sovereignty and distortion of markets. Not surprisingly then, SWFs have sparked a wave of protectionist sentiment in the more market-oriented polities.

Suspension of the voting rights of SWFs addresses one facet of the competition between market and new-mercantilist capitalism. It solves the immediate problem at which it is addressed-the use of a portfolio company's corporate governance structure to influence its decisions in a fashion that works to the advantage of the SWF's government owner at the expense of the portfolio company's other shareholders and potentially the host country itself. This solution cannot solve the larger problems that arise from the interaction of different concepts of capitalism, but it can address the most serous risk SWFs pose: that the perception of strategic behavior by foreign state-owned entities will result in a protectionist backlash. If vote suspension reduces the risk of a protectionist response, it will allow the global markets to demonstrate that, in the long run, governments make ineffective capitalists, especially where innovation is the ultimate currency. Buying time to allow the competition between the two systems of capitalism to work itself out is no small matter. 
